\title{
Decentralization and Distribution Primary Education Access in Indonesia 2014
}

\author{
Novinaz Benita ${ }^{a} *$ \\ ${ }^{a}$ Universitas Brawijaya, Malang, Jawa Timur, Indonesia
}

\section{INFORMASI ARTIKEL}

\section{Article history:}

Dikirim tanggal: 01 April 2016

Revisi pertama tanggal: April 2016

Diterima tanggal: April 2016

Tersedia online tanggal 11 Juni 2016

Keywords: decentralization, distribution primary school, Indonesia

\author{
ABSTRACT
}

This paper examines decentralisation and distribution of access to primary school in Indonesia. Data come from Indonesia National Socio Economic Survey 2014, and statistic reports from Ministry of education, Ministry Of Finance, and General Election Commision. Descriptive statistic is used to describe spatial distribution of decentralization in primary education system and distribution of primary education access. The results show there are districts disparities in decentralization of primary education system and primary education access especially between district within Java islands and Papua islands. The results highlight the need to improving decentralization performance to achieve universal primary education in Indonesia, particularly within districts outside Java islands. Improving bureaucracy capacity particularly teachers is important to improve decentralization performance in primary school access.

\section{INTISARI}

Tulisan ini mendeskripsikan akses pendidikan dasar (SD) pada masa di Indonesia pada tahun 2014. Data pendidikan berasal dari Susenas 2014 dan laporan statistik dari Kementrian Keuangan dan Komisi Pemilihan Umum 2014. Penelitian ini mengunakan analisis deskripsi statistik untuk mendeskripsikan distribusi spasial dari desentralisasi dan akses pendidikan dasar. Hasil penelitian menunjukan terdapat ketimpangan antar daerah dalam distribusi guru, anggaran pendidikan dan usia pilkada yang disertai dengan ketimpangan dalam akses sekolah dasar yang diukur dengan angka partisipasi kasar dan angka partisipasi murni. Pemerintah perlu untuk meningkatkan kinerja dari desentralisasi untuk mencapai pemerataan distribusi akses pendidikan selain itu pemerataan jumlah guru juga merupakan hal penting untuk menciptakan pemerataan akses pendidikan dasar.

2016 FIA UB. All rights reserved

\section{Introduction}

Decentralization has become development agenda across developing countriesduring the last four decades. The experiment of decen-tralization was begun in the early 1990s and took momentum in the early 2000's. The World Bank (2008) reports that it is estimated $80 \%$ of developing countries across Africa, Latin America, Asia and Eastern Europe have implemented decentralization in early 2000's. The government in these developing countries believe that decentralization can improve public services and government performance by bringing decision making closer to local people.

Many scholars explain there are any benefits of decentralizationto improving edu-cation services. For example, Fiske (1998) showsdecentralization of education sector improves the quality of learning and teaching by locating decisions closer to the point at 
which they must be carried out and be energizing teachers and administrators to do a better job. Aulia (2014) further explains that education sector decentralization bring benefits to improve education services by providing boarder authority for local government to do many things as they wish in terms of planning, determination of priority, mobilization of implementing, and education policy-making in their region. Autonomy or authority of local government within policy making about education be expected can make the region more independen particulary in enhancement access to primary education. Atsuko (2010) said decentralization in edu-cational reforms will improve quality of education and create equality. Based on above explanation, it shows that the importance of de-centralization to improve distribution of primary education access in developing countries. It is believed that decentralization policy can help government to reduce disparities in primary education access.

Opportunities to enroll in primary education in Indonesia skyrocketed in the 1980s, and thereis now almost full enrollment (Atsuko, 2010). Beside this, there are still many issues concerning primary schools. Whilst the school participation in primary school show progress but Indonesia still has confronting issues with districts disparities in eduacation access because it still under centralized system. So, the government of Indonesia has conducted decentralization since 1999. The Indonesia's de-centralization reform has changed Indonesia's education system from highly centralized system to highly decentralized system by devolving most of central government function in managing and providing primary education services to local governments.

Through this decentralization local governments have responsibility in providing and managing primary education services in their districts. This radical decentralization also brings substantial resources to local governments. Through the new intergovernmental fiscal transfer local governments have authority to planning and financing primary education sector in their jurisdiction. Through this decentralization, the governments hope that they can improve access of primary education in their districts. So, decentralization expenceted can create good distribution of primary education access.

Universal primary education has become one of national development agenda in decentralized Indonesia. However, the disparities of education access still exist because there arehigh students drop out especially in isolated area/ rural area that cause by poverty, child trafficking, early age marriage, patriarchal culture and limited infrastructures.

This research using short time series at 2014 because this research will capture the distribution of primary education access and the effect of implementation of decentralization for distribution primary education access after one decades decentralization has been implemented in Indonesia. As well as, is decentralization give problem solving for disparities primary education access disparities after one decades implemented? Based on above explanation, so this research describes and analyze the spatial distribution of primary education system primary education access in Indonesia.

\section{Theory}

\section{Decentralization}

According Atsuko (2010) decentralization is about :

"The transfer of planning, decision making, or administrative authority from central government to its field organizations, local administrative units, semi autonomous and parastatal organization, local government or non government organizations"

According to Smith (1985) Decentralization is phenomenon of political, that involving both administration and government. Government in the central transferring their power to lower levels of government hierarchy, they give authority,responsibility and resource to manage their self area. The main concept of decentralization is distribution from highest levels of government to lower levels of government. Decentralization has a boarder meaning that devide become three part namely decen-tralization in the administratively, politically and in the fiscally. According to Smith (1985), decentralization has three types:

a. Decentralization in political field introduce about democracy, democracy can give opportunity for the society to participate in development and doing control to the government, so corruption can minimalized, it measured by local election;

b. Administrative decentralization is the hierarchical and functional transfer of executive powers between different levels of government;

c. Fiscal decentralization implies that local authorities become responsible for local revenue and expenditure assignments.

Smith (1985) has categorized admi-nistrative decentralization generally using three terms, most commonly labeled deconcentration, delegation, and devolution.

a. Deconcentration occurs when the central government disperses responsibilities for certain services to its regional branch offices or Deconcentration is the process central authority establishes field units, staffing them with its own officers.

b. Delegation refers to a situation in which the central government transfers responsibility for decisionmaking and administration of public 
functions to local governments or semiautonomous organizations that are not wholly controlled by the central government but are ultimately accountable to it.

c. Devolution, refers to a situation in which the central government transfers authority for decisionmaking, finance, and management to quasi-autonomous units of local government

Faguet (2004) explains that decentralization gives benefit to the local governments possessing such preside over jurisdictions that are smaller and more homogeneous than those of national government. Local governments' decision making will thus be facilitated by not having to cater to a more diverse set of needs and wants. With superior information, participation, accountability, and policy challenges that are less onerous, it follows logically that decentralization should improve public services". Eventhough, the are several surveys of the literature really agree that empirical evidence is inconclusive. In one of the earliest reviews, for instance, Rondinelli et al. (1983) note that decentralization seldom and decentralization is just a promise. Shah (2004) agree in a review of 56 studies published since the late 1990's, note that decentralization in some cases improved, and in others worsened, service delivery, corruption and growth across a large range of countries. Treisman's (2007) more recent survey is bleaker still.

\section{Decentralization and Access to Education}

Faguet (2008) studies about decentralization's effects on educational outcomes in Bolivia and Colombia. They are using quantitative with regression method. These papers try to compare effect of decentralization on educational outcomes in two countries namely Bolivia and Colombia. The result is in Colombia, decentralization of education finance improved enrollment rates in public schools. In Bolivia, decentralization made government more responsive by re-directing public investment to areas of greatest need. In both countries, investment shifted from infrastructure to primary social services. In both, it was the behavior of smaller, poorer, more rural municipalities that drove these changes.

Namukas (2008) that doing research at Uganda. The result is decentralization of education creating a new problems in education sector because decentralization causing obscurity of role and responsibility from each institution in lower levels besides this every lower institution not equipped with good human resources.

Faguet (2004) with title "Does decentralization increase government respon-siveness to local needs? Evidence from Bolivia". This research using quantitative with regressionanalysis. This research shows investment pat-terns in human capital and social services changed significantly after decentralization. The-se changes are strongly and positively related to objective indicators of need. Nationally, these changes were driven by the smallest, poorest municipalities investing devolved funds in their highest-priority projects.

Decentralization significantly changed pu-blic investment patterns in Bolivia. Throughout the country, investment changed unambiguously in education, water and sanitation, water mana-gement, agriculture and urban development after the 1994 reform. And these shifts are strongly and positively related to real local needs. In education, water and sanitation, water management, and agriculture, postdecentralization investments are higher where illiteracy rates are higher, water and sewerage connection rates lower, and malnutrition a greater risk, res-pectively.

Shah (2004) also doing the research about decentralization of education with the title contextual issues in decentralization of primary education in Tanzania.The result is decen-tralization of education in Tanzania create an obscure and ambiguous commitment among the political elite and administrative within decentralized primary education.

Huda and Hadi (2012) with title analysis impact of fiscal decentralization to public services outcomes in education field (study at DKI Jakarta). This research try to make relation between the effect of fiscal decentralization to education outcome and data that used in this research is data come from all of city and district at Jakarta Province in 2006-2010. The result from this research is the effect of fiscal decentralization to school participation number is not significant so can be deduce fiscal aid that given by central government to local government is not bring effect to improvement of school participation rate children in school age.

Aulia (2014) show if implementation of education decentralization at Surabaya city can give opportunity to all children in the school age to get education from elementary school until high school, they can school without pay. Surabaya City Government has board authority and real to make planning, making decision, managing, and giving legal protection for education implementation in their region. The financial support for funding this program is come from operational expanse for local education or usually called by BOPDA. The source of BOPDA is come from local government budget (APBD), BOPDA allocated to all education operator at Surabaya City, begin from elementary school until high school. So, decentralization of education at Surabaya has result a policy about study compulsory 12 years with supported by free cost. 
Namukas (2009) had a research with the title is "Indonesia: Overcoming Chal-lenges of Decentralization". He discuss about the challenge within implementation decentralization on education process. The result is, decentralization produce dual management system within management of primary education, dual management is come from Ministry of education and Cultural and second appear from ministry of religious affairs that usually manage Islamic public school. dual management make ambiguous.

Bambang (2013) studies decentralizing education in Indonesia. This research using combination of qualitative and quantitative method (using Anova and correlation test). Anova is using for analyzed means differences in participation rates in schools for all children aged 5-18 in among districts (Bantul, Mataram, Kutai and Ngada ) and households sources of income and expenditure levels. Correlation test is for tested the correlation between participation rates and the number of children and parents levels of education in the interviewed households. The result from this research is there is a total lack of transparency and accountability in government spending on education after the decentralization reform.

According to ANOVA analysis, the lowest participation rate in education is in Ngada and the higher is in Bantul, Kutai Kartanegara is higher than in both Mataram and Ngada, while Mataram scores significantly higher than Ngada. Refer to corelationtest households with agriculture as their main source of income have significantly lower participation rates in schooling for their children compared to families with other sources of income. From this research can conclude: First, the consequences of the decentralization policy for education sector is negative. Second, the administration of educational services is without transparancy and accountability.

Aulia (2014) examines fiscal decentralization and disparity of access to primary education in Indonesia duing 2005 until 2009. They are using quantitative method with fix effect approach regression. The aims from their research is to analyze the impact of fiscal decentralization in reducing disparity in the enrollment of primary education in Indonesia. Their result is DAK for Education, DAK Non Education, and PAD have significant impact in reducing education access disparity along with poverty and regional characteristic such as Java-non Java regions. For education level, another variable was also found significant including education of the society and regional characteristic such as proliferated-non proliferated regions. In general there is a facts and proves that fiscal decentralization improve education access equality, but several effort need to done to optimize the equalization of primary education access in Indonesia.
This research differs with these previous studies in several ways. First, it uses district level data as unit analysis. By using district level data rather than provincial level data, this research may capture accurately the distribution of primary school access in Indonesia. Second, this research used all data of districts level in Indonesia. Therefore, the results can be generalized in the national level in 2014

\section{Hipothesis}

According theoritical dialogue about decentralization and distribution access to primary school, so this reserach purpose one hypothesis thats Decentralization will create equality in the distribution of primary school in Indonesia.

\section{Research Method}

To describe and to analyze the distribution of primary education access in Indonesia 2014, so this research using statistic report from Ministry Of Education and Culture (MOEC), Ministry Of Finance (MOF) and general elections commision. Data that come from Ministry Of Education and Culture (MOEC) is consist of GER and NER primary school in Indonesia 2014 and distribution teachers in every district. Ministry of Finance (MOF), related to the education spending data like total transfers education budget from central government in every districts. General Elections Commision, related with data of local election in every districts.

\section{Decentralization and distribution primary school access}

Distribution of primary school is measured by GER and NER. Refrens to United Nation (2003). The net enrolment ratio (NER) refers to the enrolment of the official age group for a given level of education expressed as a percentage of the corresponding population. The gross enrolment ratio (GER) refers to the total enrolment in a specific level of education, regardless of age, expressed as a percentage of the official school-age population corresponding to the same level of education.

In this research decentralization is devide became 3 parts. Administrative, political and fiscal decentralization. Administrative decentralization is measured by the distribution of teachers within districts. Shah (2004) explains administrative decentralization is transfer authority from central government to fungtionary in local level which are in the same hierarchy line. The fungtionary got assigment and responsibility from central government in the spesific field as the central departement representative. For 
example, in the field education sector is teachers transfer or distribution teachers to all districts. Atsuko (2009) also using teachers as the measured of administrative decentralization in education.

Fiscal decentralization is measured by district education budget from central government to district government and general allocation fund for education. According previous research, Atsuko (2009) using general allocation fund for teachers sallaries as the variables. Political decentralization is measured by the age of local democracy of district. Smith (1985) explains decentralization is tend to how far the democratic political process that excuted in the local area and local election is one of clear indicator for measuring political decentralization.

\section{Statistical analysis}

Analysis data is one of processs that doing after all of data that needed for give solution to the problems in the studied already full obtained. The sharpness and precision in the using analytical tools very determine the accuracy of the conclusion. Therefore the data analysis is an activity that can not be ignored in the research process. Analysis method technique in this research is using descriptive statistic. Descriptive statistic is statistic that used for data analyze with describe and making picture of the data that has been collected but without making general conclusion.

This research using descriptive statistic because in this reserach doing in population without using sample. Descriptive statistic is data presentation that using frequency distribution table, graphic, pie chart, pictogram, mode, median, mean, calculating the average, standard deviation and percentage (Sugiyono, 2013). Descriptive statistic in this reserach using graphics to explain distribution of primary education access and relationship between decentralization and access to primary education.

\section{Results and Discussion}

\section{Results}

\section{Access to primary school}

In the effort on developing the education in Indonesia. Central government give fund to help every districts within improvement number of enrollment rate as a form fiscal decentralization.

The number of total transfer from central government to every districts is different. Figure 1 is show the five regions that got lowest education budget. Like in Membramo that is only 27 million and Intan Jaya only 22 million Majority regions is a part of Papua Province. It is really different with any big city in
Indonesia that got big amount of fund for education like Bandung Regency 1,7 billion, Malang Regency 1,29 billion and Palembang 1,26 billion. It proven by figure 2 that show regions that got bigest transfer from central government.

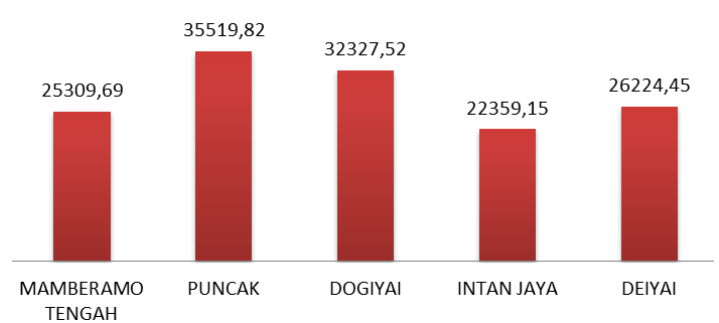

Figure 1 Total transfer education budget (Source : Researcher, based on MOF data)

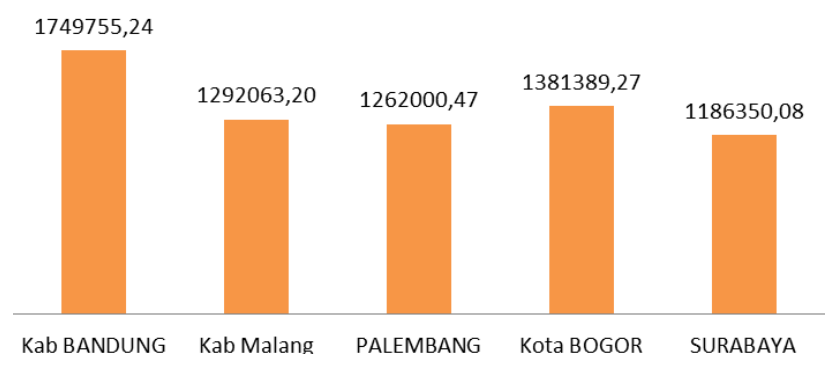

Figure 2 Highest Total transfer education budget (Source : Researcher, based on MOF data)

\section{Fiscal decentralization}

Transfer from central government bring impact to quality of teachers in every district. quality of teachers as administrative decentralization is measured by distribution of qualified teachers. Qualified teacher is a teacher whom already fulfill academic qualification specifically in bachelor degree. In Figure 3 show district that have high number of qualified teachers.

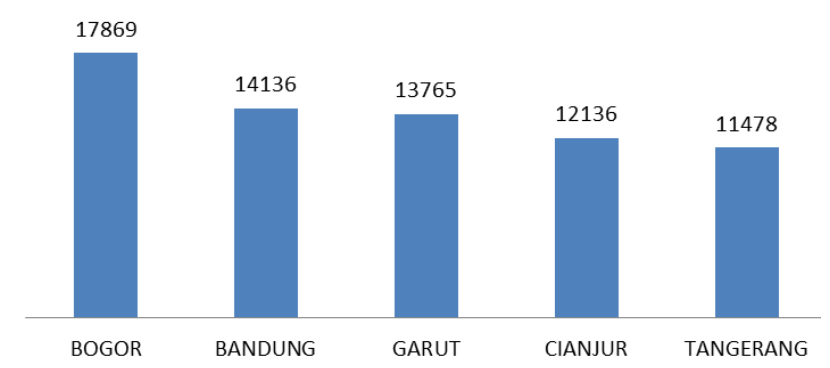

Figure 3 Number of Qualified Teachers (Source : Researcher, based on MOF data)

Generally, the number of qualified teachers in Indonesia only focused in Java and big cities. Refers to Figure 3, Bogor has highest number of qualified teachers thats 17.869, Bandung 14.136, Garut 13.765, Cianjur 12.136 and Tangerang 11.478 teachers. It is really different with number qualified teachers in Papua Province. 


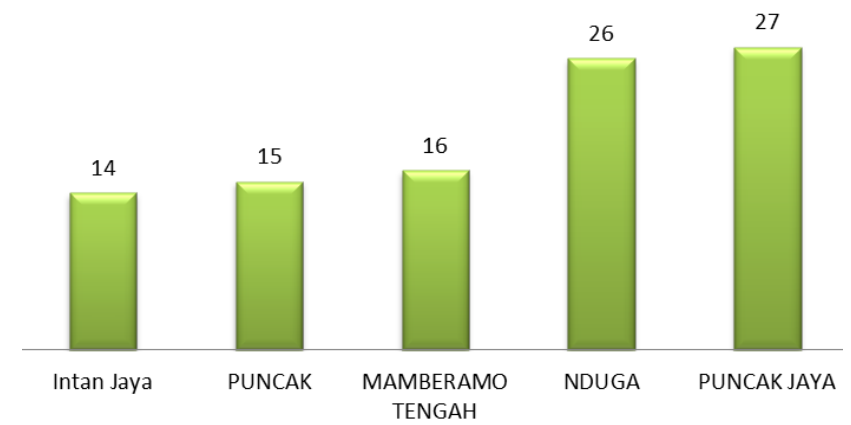

Figure 4 Number of Qualified Teachers in Papua

(Source : Researcher, based on MOF data)

Highest disparity in the process of providing qualifued teachers is between Java and Papua. The Number of qualified teachers in Java is very high such as Bogor Regency with 17.869 teachers, Garut with 13.765 teachers whilst in Papua the number of teachers is very low. For example in Intan Jaya is just 14 person, Puncak jaya there are only 27 qualified teachers, and in Nduga just 26 teachers.

\section{Political decentralization}

Political decentralization aims is to give citizens and their elected representatives more power in public decision making. Decentralization involve civil society participation in the process of decision making. Smith (1985) explains decentralization is tend to how far the democratic political process that excuted in the local area and local election is one of clear indicator for measuring political decentralization. Local democracy describes the period of local election in every districs. The period of local election is one of the factors to see whether the region is already mature enough to take decision or are they still newbie. Decision making give effect within the success of primary education.

Local democracy in every districts has different age because there are many division area that belong to new area so they have younger period of time doing democration process but also there are regions that has been executing local election for a long time. The regions that has younger age and time period of election will surely adapt to manage their area especially in the term of policy, it is different with region that has been long to carrying out democratic. They are more capable to make decision for public policy because policy that has been made refers to people's aspirations.

Election period provides an overview maturity of a region within the making of public policies. Regions that have longer period of election indicates that they are more able to solve their problems and meet the needs of citizens according to the people's aspirations. Remember, experience in the running of the democratic governance more long time than regions that aged of election more younger. Many regions in Indonesia have different period of election. Most of regions in Indonesia already has a long period of election, but many other regions also have short period of election because of the are area division.

Primary school access during decentralization in Indonesia 2014

Figure 5 describes the distribution of enrollment rate primary education in highest and lowest performing districts. GER describes and let us know the enrollment rate in every regions without considering about age. So, if the GER is close to $100 \%$ or more than $100 \%$ it means that the enrollment rate in general is high, although there are still many people who attend school that are not appropriate with their age.

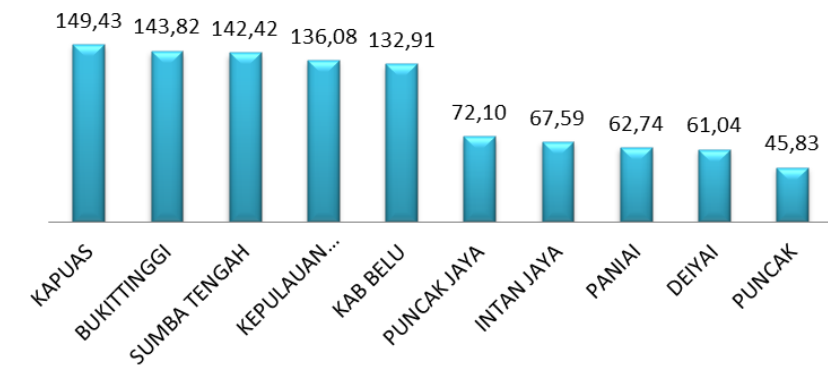

Figure 5 GER Elementary School (Source : Researcher, based on MOF data)

The figure shows fifth region with highest and lowest GER in Indonesia. Kapuas became region with largerst GER in 2014 that is $149,43 \%$, and than Bukittinggi 143,8\%, Sumba Tengah 142,42\%, Kepualauan Mentawai 1365 and Belu is $132 \%$. Many district in papua Province still has lowest GER like in Puncak Jaya, Intan Iaya, Kab. Puncak, Paniai, and Deyai.

Among others namely above $50 \%$, green shows NER in the region is about $70 \%$, blue shows that NER is about $80 \%$ and purple means that the NER in the region is the largest among others namely about $90 \%-100 \%$.

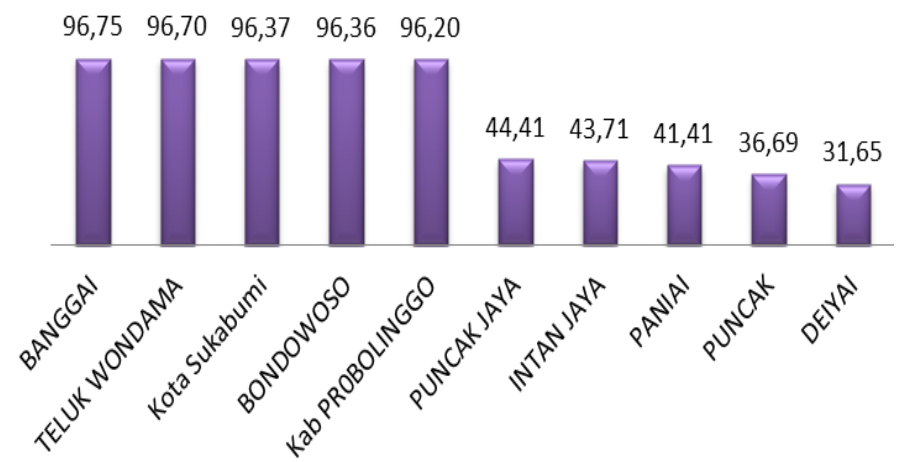

Figure 6 Distribution of NER Elementary School (Source : Researcher, based on MOF data) 
Figure 6 shows district that has high and low distribution of Net Enrollment Rate (NER) elementary school. Bangga, Teluk Wondana, Sukabumi, Bondowoso and Probolinggo is regions that has high NER and Puncak Jaya, Intan jaya, Paniai, Puncak and Deiyai is region that has lowest NER.

\section{Discussion}

Decentralization of education is one such reform, which emerged in the 1980s and today has almost become a global phenomenon and it is a common theme in the recent educational reforms of developing countries. It became global phenomenon because decentralization is perceived can helps reduce inequilities in provision and access education services and improves efficiency. Shah (2004) defined decentralization as the transfer of authority for decision making, finance and management to quasi autonomous units of local government.

It is possibly decentralization became most advocated measure for increasing the provision of education services because the existance of decentralization expected can increase access to primary education and bring equality in the provision primary education access.

The result from this study shows sharp contrast with scholars argument because since decentralization has been implemented, it is not yet solved problems inequality in primary education access services. Although de-centralization of primary education in Indonesia have goals to creating equality in the distribution of education access but after few years, equality in primary education access is still only a dream. The evidance is showed from the distribution enrollment rate in primary school, education spending, teachers dis-tribution. So from those explanation in above can concluded that decentralization in Indonesia relate to regional disparities particulary at districts between Java and outside Java in the distribution access of primary education.

\section{Conclusion}

Disparities of education services and access of primary education exist, particularly between urban and remote areas of Papua, Sulawesi and Kalimantan islands. Not only disparity the enrollment rate of primary school but also in the Distribution of education spending indicates disparity. The disparity is may influenced by number of population. Distribution teachers also show inequality, it may lead to amount of qualified teachers is more bigger in district in Java and they think in Java is more easier and there are financial constraints, compare with other occupation working teachers in the isolated area that usually have low salaries and many regions in Indonesia have different period of election. Most of regions in Indonesia already has a long period of election, but many other regions also have short period of election because of the are area division. This research highlights the need to improving decentralization performance to achieve universal primary education in Indonesia, particularly within districts outside Java islands. Improving bureaucracy capacity particularly teachers is important to improve decentralization performance in pri-mary education access.

This research still has a weakness and limitation because still using short time series for analysis and just analyze distribution of primary school. So, for next research hopefully can using long time series since decentralization has been implemented in Indonesia begin 2002 until now and can capture the trend of primary education as well as primary and secondary school distribution.

\section{Recomendation}

a. Governments should be more focused to develop access of primary education in the isolated area and outside Java in order to make equalization. Central government must have an attention on local government and local government must keep in touch with central government so the local government's needs can be fullfiled and enrol-lment rate can increase.

b. Distribution of teachers must be focused in the regions that has low enrollment rate, especially in isolated areas, in Papua and Suburban areas. Government should make programs to increase the teachers salaries in the isolated areas, to attract teachers to teach in the isolated areas.

c. Central government must to improve monitoring and evaluation of primary education in isolated area, especially in district thas has low access. Therefore, disparity on primary education access can minimize because central government know directly the development of primary education access condition and they can immediately fulfill the need to support the learning process.

\section{Refferences}

Atsuko, H. (2010). An Empirical Study Of The Effect Of Decentralization In Indonesian Junior Secondary Education. Springer Science, March, pp.107-125.

Aulia, M. (2014). Desentralisasi Kebijakan Pendidikan (Studi Tentang Pelaksanaan Wajib Belajar 12 Tahun Di Kota Surabaya Pada Tingkat 
Pendidikan Menengah dan Kejuruan). Surabaya : Unair.

Bambang, B. (2013). Indonesia: Overcoming Challenges of Decentralization. Jakarta: The Center For Policy Research Ministry Of Education.

Smith, B. (1985). Decentralization The Territorial Dimension Of The State. George Allen Publisher, London.

Faguet, J.P. (2004). Does decentralization increase government responsiveness to local needs? Evidence from Bolivia. Journal of Public Economics, Vol 88, pp. 867-893.

.2008. Decentralization's Effects on educational outcomes in Bolivia and Colombia. Science Direct. World Development Vol. 36, No. 7, pp. 1294-1316.

Fiske, R. (1998). Arah Pembangunan Desentralisasi Pengajaran Politik dan Konsensus. Jakarta: Grasindo.

Huda, H. (2012). Analisis Dampak Desentralisasi Fiskal Terhadap Outcomes Pelayanan Publik Bidang Pendidikan (Studi kasus: Provinsi DKI Jakarta). Semarang: Diponogoro University.

Namukas, M. (2009). Decentralization And Education In Africa: The Case Of Uganda. Springer Science + Business Media, pp. 175-195.

Shah, A. (2004). "The impact of decentralization on service delivery, corruption, fiscal management and growth in developing and emerging market economies: A synthesis of empirical evidence." CESifo DICE Report, 1/2004: 10-14.

Sugiyono. (2013). Statistika Untuk Penelitian. Bandung: Alfabeta. 